УДК 340.134: 339.7: 336.74

DOI https://doi.org/10.32837/pyuv.v0i2(31).571

\author{
Г. О. Бухарін \\ orcid.org/0000-0003-3797-4274 \\ аспірант кафедри адміністративного та господарського права \\ Запорізького національного університету
}

\title{
ДОСЛІДЖЕННЯ ПІДХОДІВ НОРМАТИВНО-ПРАВОВОГО РЕГУЛЮВАННЯ ГАЛУЗІ ФІНТЕХ НА ПРИКЛАДІ РЕГУ ЛЮВАННЯ ДІЯЛЬНОСТІ УСТАНОВ - ЕМІТЕНТІВ ЕЛЕКТРОННИХ ГРОШЕЙ
}

Активний розвиток фінтех-індустрії та фінтех-стартапів в останнє десятиліття актуалізував необхідність нормативно-правового врегулювання сфери фінансових технологій.

Питання розвитку фінансових технологій загалом i ix нормативно-правового регулювання зокрема через його актуальність є об'єктом дослідження багатьох вітчизняних і зарубіжних вчених та практиків, серед яких: Л. Дудинець [5], Н. Пантєлєєва [8], С. Паперник та О. Молотай [9], Г. Поченчук [10], С. Шкарлет, М. Дубина й О. Жук [11], М. Яценко й А. Бондаренко [12], Д. Паніна [7], В. Вайпан, Є. Губін і М. Сгорова [1], В. Загойті [6], А. Діденко [14], П. Гупта [17], Ф. Годіно [16], М. МакКеффрі й А. Шифф [18], Ч. Тейлор, К. Уілсон, Е. Холтінен та А. Морозова [19], М. Амстад [13] та ін. Тим не менш, з огляду на динамічний розвиток галузі фінтех питання ï нормативно-правового регулювання не може вважатися вирішеним навіть за наявності грунтовних досліджень, а специфічні особливості фінансових технологій потребують більш детального вивчення $з$ метою створення якісної екосистеми для їхнього подальшого розвитку.

Як зазначає дослідник питання нормативно-правового регулювання системи електронних платежів Д.С. Паніна [7], у світовій практиці сьогодні склалися два основні підходи: ліберальний і нормативний, відображені у формуванні трьох основних моделей електронних платежів: азійській, європейській та американській, кожна з яких має свої особливості.

Найбільш жорсткою політикою регулювання відрізняється азійська модель, у рамках якої зафіксована державна монополія на випуск електронних грошей (наприклад, Сінгапур і Тайвань) та обмежений доступ для іноземних компаній до системи електронних платежів (Китай) із метою усунення внутрішніх і зовнішніх загроз для національної платіжної системи, протидії відмиванню доходів, отриманих злочинним шляхом, і мінімізації вірогідності реалізації імпортованих розрахунково-платіжних ризиків. Так, на території Китаю передбачена єдина легальна можливість для здійснення іноземних транзакцій - через єдину систему електронних платежів China Unionpay Data, a іноземні компанії не можуть створювати платіжні системи й емітувати платіжні картки самостійно - відповідна діяльність можлива лише за умови залучення китайських компаній.

Таким чином, досвід азійських країн, який у повному обсязі відображає нормативний і механістичний підходи до правового регулювання галузі фінтех, свідчить про доцільність створення регульованого ринку електронних платіжних послуг за умови дійсно ефективного державного регулювання, що передбачає створення законодавчої бази та відповідних заходів податкового стимулювання, а це сприятиме інтенсивному розвитку ринку електронних платіжних систем.

Полярні думки щодо застосування підходів до нормативно-правового регулювання галузі фінтех (на прикладі електронної індустрії) простежуються у США, де відбувається активна взаємодія офіційних банків із небанківськими (нефінансовими) посередниками у сфері електронних розрахунків і платежів. Законодавством передбачена участь небанківських установ як посередників (платіжних агентів) на американському платіжному ринку, що відображено у можливості інвестиційної участі банків і банківських холдингів у капіталі небанківських емітентів карт зі збереженою вартістю загального призначення. Таким чином, у США більш прийнятним традиційно вважається ліберальний підхід. Обгрунтуванням цієї позиції виступає об'єктивна реальність динамічного розвитку системи електронних платежів як складної структури, розвиток якої вимагає постійного залучення інновацій. Відповідно, функція держави повинна фокусуватися лише на створенні умов для розвитку конкуренції [7].

Країни Європейського Союзу на етапі започаткування галузі фінтех і створення відповідних правових норм також більшою мірою дотримувалися нормативного підходу до правового регулювання, застосовуючи жорсткий нагляд за емісією та обігом електронних грошей.

У цьому контексті доречно навести й іншу класифікацію, котру поділяють дослідники механізмів нормативно-правового регулювання фінтеху В.О. Вайпан, Є.П. Губін, М.О. Єгорова [1] та В.Л. Загойті [6], за якою також виділяють два підходи до нормативно-правового регулювання впровадження і застосування фінансових інновацій: превентивний і вичікувальний. Перший підхід превентивний, заснований на використанні про- 
гнозних результатів. Зазначений підхід доцільно дослідити на показовому прикладі еволюції нормативно-правового регулювання заснування та діяльності установ-емітентів електронних грошей, починаючи з першої редакції Директиви Європейського парламенту і Ради ЄС (Директива 2000/46/ ЄC) від 18 вересня 2000 р. про заснування, регулювання та пруденційний нагляд за діяльністю установ, які емітують електронні гроші [15], прийнятої з метою досягнення необхідної гармонізації законодавства для забезпечення взаємного визнання дозволу та пруденційного нагляду за установами, котрі емітують електронні гроші, що робить можливим надання єдиної ліцензії, визнаної в усьому Співтоваристві та розробленої для забезпечення довіри суб'єктів фінансових відносин і застосування принципу пруденційного нагляду в державах-членах $\mathrm{EC}$.

Наведена редакція Директиви $(2000 / 46 / € C)$ визначає протиправність діяльності з випуску електронних грошей суб'єктами, які не є кредитними установами за визначенням Директиви 2000/12/ЄС, і забороняє в особі держав-членів ЄC будь-яким іншим особам чи установам випуск електронних грошей. Кредитною установою за визначенням Директиви Європейського Парламенту та Ради ЄС «Щодо започаткування діяльності кредитних установ та їі ведення» від 20 березня 2000 р. (Директиви 2000/12/ЄС) [2] є суб’єкт підприємницької діяльності, діяльність котрого полягає в отриманні від громадськості депозитів або інших коштів на зворотній основі та надання кредитів за свій власний рахунок.

Директива (2000/46/ЄC) надає нормативно-правову дефініцію поняттю «установа, яка емітує електронні гроші» та визначає їі як підприємство або будь-яку іншу юридичну особу, крім кредитної установи, визначеної у пп. (а) ст. 1 п. 1 Директиви 2000/12/ЄС, що видає платіжні засоби у формі електронних грошей. Поняття «електронні гроші» визначено як грошову вартість, яка:

- зберігається на електронному пристрої;

- видається при отриманні грошових коштів на суму не меншої вартості;

- приймається як платіжний засіб іншими підприємствами, ніж емітент.

Ст. 1 п. 4 та п. 5 аналізованої Директиви забороняє особам чи підприємствам, котрі не є кредитними установами за визначенням Директиви 2000/12/ЄС, ведення діяльності з випуску електронних грошей. Інша ділова діяльність установ, які емітують електронні гроші (окрім випуску електронних грошей), обмежується до таких напрямів діяльності:

- надання тісно пов'язаних фінансових і нефінансових послуг, таких як: адміністрування електронних грошей шляхом виконання оперативних та інших допоміжних функцій, пов'язаних із їх видачею, видача й адміністрування інших платіжних засобів, але виключаючи надання будьякої форми кредитування;

- зберігання даних на електронному пристрої відіменіінших підприємств чи державних установ.

Установи, які емітують електронні гроші, згідно з першою редакцією Директиви не повинні мати жодних фондів в інших підприємствах, за винятком випадків, коли ці підприємства виконують оперативні чи інші допоміжні функції, пов'язані з електронними грошима, виданими або розподіленими відповідною установою.

Еволюція правовідносин із випуску й обігу електронних грошей призвела до відповідних змін нормативно-правового регулювання діяльності установ-емітентів електронних грошей. У подальшій редакції Директиви установам-емітентам вже дозволено випускати засоби платежу, включаючи електронні гроші, й управляти ними, а також здійснювати таку діяльність на території всього Співтовариства на основі взаємного визнання i всеохоплюючої системи пруденційного нагляду, яка застосовується до них згідно із Директивами ЄC з питань банківської діяльності відповідно до п. 5 Додатка 1 до Директиви 2000/12/ЄС.

Передбачено введення особливого порядку пруденційного нагляду за установами-емітентами електронних грошей, який, хоч і приведений у відповідність із порядком пруденційного нагляду, що застосовується до інших кредитних установ, все ж відрізняється від нього, і це є виправданим і бажаним, оскільки сам по собі випуск електронних грошей, враховуючи їх специфічний характер як електронного замінника монет і банкнот, не включає в себе приймання вкладів згідно зі ст. 3 Директиви 2000/12/ЕС [3].

Вказана редакція Директиви (2000/46/ЄC) зазначає необхідність забезпечення регулятивної основи електронної торгівлі, яка швидко розвивається, у більш широкому контексті, що допоможе повною мірою виявити потенційні переваги електронних грошей i, зокрема, уникнути затримки впроваджень технологічних нововведень. Тому ця Директива вводить технологічно нейтральну правову основу, яка гармонізує пруденційний нагляд за установами-емітентами електронних грошей у межах, необхідних для забезпечення їх фінансово надійного та розсудливого функціонування i, зокрема, їх фінансової цілісності.

Аналізовані Директиви втратили чинність на основі Директиви 2009/110/EC «Щодо започаткування та здійснення діяльності установами-емітентами електронних грошей і пруденційний нагляд за ними, що вносить зміни до Директив $2005 / 60 /$ EC та 2006/48/EC і скасовує Директиву 2000/46/EC» від 16 вересня 2009 р. [4], тим не менш, проведений аналіз нормотворчості є доціль- 
ним із погляду простеження еволюції розвитку підходів до нормативно-правового регулювання та контролю у галузі фінтех. Чинна редакція приведена у відповідність із сучасними вимогами розвитку фінтеху і свідчить про застосування іншого підходу до нормативного-правового регулювання впровадження та застосування фінансових інновацій - вичікувального, який полягає у вдосконаленні нормативно-правового регулювання об'єкта внаслідок звершення відповідних змін внутрішнього об'єктивного та зовнішнього галузевого середовища. Адже, як зазначено в наведеній редакції Директиви, її було ухвалено у відповідь на появу нових попередньо оплачених продуктів для здійснення електронних платежів, із чого можна зробити висновок, що процес формування чинних правових норм із регулювання та контролю емісії електронних грошей у країнах ЄС має послідкові ознаки та є результатом еволюції самої галузі фінтеху, зокрема інструментарію обігу електронних засобів платежу з метою стабілізації внутрішнього ринку та забезпечення належного рівня пруденційного нагляду.

Значною перевагою чинної редакції Директиви $€$ спрощення вимог до діяльності установ-емітентів електронних грошей щодо розміру уставного капіталу, рівень якого був знижений із 1 млн євро до 350 тис. євро, та фіксацією права повернення користувачем грошових коштів у будь-який момент часу, чого не передбачалося в перших редакціях Директиви.

Удосконалено визначення і самого поняття «електронні гроші» з огляду на необхідність введення чіткої та нейтральної з технологічного погляду дефініції, що повинна передбачати всі варіанти емісії постачальником платіжних послуг попередньо оплаченого засобу розрахунку в обмін на грошові кошти, який можна використовувати для оплати. Це передбачає наявність грошової вартості, що зберігається або на платіжному пристрої, який знаходиться у розпорядженні власника електронних грошей, або на віддаленому сервері й управління яким здійснюється власником електронних грошей через передбачений для цього спеціальний рахунок.

Директивою вводиться обов'язкова вимога щодо необхідності достатньо широкого визначення $з$ метою уникнення затримки у впровадженні технологічних нововведень та охоплення не тільки всіх видів електронних грошей, наявних на сучасному ринку, а також і тих продуктів, які можуть з'явитися у майбутньому, що знову підтверджує застосування другого аналізованого підходу до регулювання впровадження і застосування фінансових інновацій - вичікувального.

Значна увага чинною Директивою приділена питанню захисту користувачів і забезпеченню надійності у роботі установ-емітентів електронних грошей, запроваджуючи обов'язок передбачення та впровадження додаткових методів розрахунку поточного капіталу, також обов'язок для установ-емітентів електронних грошей зберігати кошти власників електронних грошей окремо від коштів установи-емітента, призначених для інших видів діяльності. Директивою встановлені імперативні норми щодо дотримання установами-емітентами електронних грошей чинного законодавства у сфері контролю за відмиванням грошей i фінансуванням тероризму.

Таким чином, відповідно до об'єктивних процесів динамічного розвитку фінансових технологій законодавство ЄС із нормативно-правового регулювання галузі фінтех пом'якшує початковий превентивний (нормативний, механістичний) підхід до правового регулювання аналізованої сфери шляхом прийняття поправок ліберального характеру, що зумовлено втратою актуальності початкових нормативно-правових норм.

Висновки. Проведений аналіз еволюції нормативно-правового регулювання діяльності установ-емітентів електронних грошей свідчить про неоднозначність окремих підходів до регулювання впровадження і застосування фінансових інновацій, адже через стрімкий розвиток об'єкта дослідження та регуляції - фінтеху - необхідно вказати про особливу складність (майже неможливість) впровадження відповідних законодавчих змін, що може призвести до надмірного контролю компетентних органів за галуззю, стримування ii розвитку, особливо у разі застосування механістичного, нормативного та превентивного підходів (за різними класифікаціями) до нормативно-правового врегулювання об’єкта дослідження.

Загалом проведене дослідження підходів до нормативно-правового регулювання та контролю галузі фінтех на прикладі нормативно-правового регулювання діяльності установ-емітентів електронних грошей засвідчило наявність певних факторів, які найбільшою мірою впливають на специфіку процесу нормативно-правового регулювання та визначення того чи іншого підходу до нього.

\section{Jimepamypa}

1. Вайпан В.А., Губин Е.П., Егорова М.А. Правовое регулирование экономических отношений в современных условиях развития цифровой экономики. Москва : Юстицинформ, 2019. $376 \mathrm{c.}$

2. Директива 2000/12/ЄC Європейського Парламенту та Ради СС «Щодо започаткування діяльності кредитних установ та її ведення» від 20 березня 2000 р. URL: https://zakon.rada.gov.ua/laws/show/994_277 (дата звернення: 23.03.2020).

3. Директива 2000/46/ЄС Європейського Парламенту та Ради ЄС «Про започаткування та здійснення діяльності установами-емітентами електронних грошей та пруденційний нагляд за ними» від 18 вересня 2000 p. URL: https://zakon.rada.gov.ua/laws/ show/994_178 (дата звернення: 23.03.2020). 
4. Директива 2009/110/EC «Щодо започаткування та здійснення діяльності установами-емітентами електронних грошей та пруденційний нагляд за ними, що вносить зміни до Директив $2005 / 60 / \mathrm{EC}$ та 2006/48/EC, та скасовує Директиву 2000/46/EC» від 16 вересня 2009 p. URL: https://zakon.rada.gov.ua/laws/show/ 994_a18 (дата звернення: 23.03.2020).

5. Дудинець Л.А. Розвиток фінансових технологій як фактор модернізації фінансової системи. Глобаль ні та національні проблели еконоліки. 2018. Вип. 22. C. 794-798.

6. Загойти В.Л. Зарубежный опыт регулирования финансовых технологий. Journal of Economy and Business. 2018. Вып. 5. Ч. 1. С. 77-79.

7. Панина Д. С. Особенности регулирования индустрии электронных платежей: опыт зарубежных стран. Вестник Оренбургского государственного университе ma. 2015. № 4 (179). C. 313-317. URL: http://vestnik. osu.ru/2015 4/52.pdf (дата звернення: 20.03.2020).

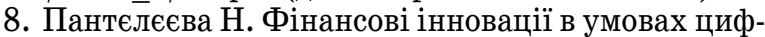
ровізації економіки: тенденції, виклики та загрози. Приазовський економічний вісник. 2017. Вип. 3 (03). C. 68-73. URL: http://pev.kpu.zp.ua/journals/2017/ $303 \mathrm{uk} / 17 . p d f$ (дата звернення: 23.03.2020).

9. Паперник С., Молотай О. Огляд правових аспектів в галузі ФінТех в Україні. Evris.Law. URL: https://evris.law/uk/stattja-ogljad-pravovih-aspektivv-galuzi-finteh-v-ukraini/ (дата звернення: 22.03.2020).

10. Поченчук $\Gamma$. Finтесh у структурі фінансової системи. Глобальні та національні проблели еконоліки. 2018. № 21. C. 49-55. URL: http:/ /global-national.in.ua/ archive/21-2018/11.pdf (дата звернення: 20.03.2020).

11. Шкарлет С.М. Дубина М.В., Жук О.С. Теоретичні аспекти визначення сутності категорії «Fintech». Науковий вісник Полісся. 2019. № 1 (17). С. 148-157.

12. Яценко М.С., Бондаренко А.О. Актуальні питання розвитку сектору фінансових послуг із застосуванням сучасних фінансових технологій. Держава та регі они. Серія : Еконоліка та підприємниитво. 2019. № 2. C. 25-30. URL: http://www.econom.stateandregions. zp.ua/journal/2019/2_2019/6.pdf (дата звернення: 23.03.2020).

13. Amstad M. Regulating Fintech: Objectives, Principles, and Practices. SSRN Electronic Journal. 2019. URL: http://dx.doi.org/10.2139/ssrn.3491982 (дата звернення: 22.03.2020).

14. Didenko A. Regulating FinTech: Lessons from Africa. SSRN Electronic Journal. 2018. URL: http://dx.doi.org/10.2139/ssrn.3135604 (дата звернення: 20.03 .2020$)$.

15. Directive 2000/46/EC of the European Parliament and of the Council of 18 September 2000 on the taking up, pursuit of and prudential supervision of the business of electronic money institutions. URL: https://eur-lex.europa.eu/legal-content/EN/ALL/?uri= CELEX\% 3A32000L0046 (дата звернення: 21.03.2020).

16. Gaudino B.F. The FinTech Ecosystem Between Legal Compliance and Social Dimension. The RegTech Book. 2019. URL: https://doi.org/10.1002/9781119362197. ch57 (дата звернення: 23.03.2020).

17. Gupta P. Chapter 25. Legal Implications of Fintech. Fintech: The New DNA of Financial Services (p. 453-488). Berlin, Boston : De Gruyter. 2018. URL: https://doi.org/10.1515/9781547400904-025 (дата звернення: 22.03 .2020$)$.

18. McCaffrey M. and Schiff A. Finclusion to Fintech: Fintech Product Development for Low-Income Markets. SSRN Electronic Journal. 2017. URL: http://dx.doi.org/10.2139/ssrn.3034175 (дата звернення: 23.03.2020)

19. Taylor C., Wilson C., Holttinen E., Morozova A. Institutional Arrangements for Fintech Regulation and Supervision. FinTech Notes. 2020. № 19 (02). URL: https://doi.org/10.5089/9781513520308.063 (дата звернення: 23.03.2020).

\section{Анотація}

Бухарін Г. О. Дослідження підходів нормативноправового регулювання галузі фінтех на прикладі регулювання діяльності установ - емітентів електронних грошей. - Стаття.

У статті визначено дієві підходи до нормативно-правового регулювання галузі фінтех та обгрунтовано доцільність їх подальшого застосування у нормотворчій діяльності та правозастосовній практиці. Підходи до нормативно-правового регулювання галузі фінтех були розглянуті на прикладі діяльності установ-емітентів електронних грошей, наведені та проаналізовані класифікації підходів і критерії, за якими вони формуються. Світова практика нормативно-правового регулювання та контролю галузі фінтех, незважаючи на достатню інноваційність аналізованого феномену, $\epsilon$ досить розгалуженою та відрізняється специфічними особливостями в різних країнах впровадження.

3 метою аналізу особливостей механізмів нормативно-правового регулювання та контролю галузі фінтех розглянуто існування традиційного механістичного підходу як відображення механістичної концепції правового регулювання щодо більшості правовідносин, які виникають у сфері фінтеху, що є доречним на початковому етапі розвитку фінтех-правовідносин. Тим не менш, зважаючи на стрімкий розвиток фінтех-індустрії та пов'язаних із нею специфічних правовідносин, констатовано застосування системного підходу до нормативно-правового регулювання та контролю галузі фінтех як більш дієвого, що врахує об'єктивні процеси самоорганізації та саморегулювання сучасних систем, розвиток різноманіття системоутворюючих зв'язків та інтенсивної інтеграції правових норм і правовідносин як прояву інтегративної юриспруденції.

Представлені моделі електронних платежів: азійська, європейська й американська, кожна зі своїми специфічними особливостями, перевагами та недоліками. Досліджена еволюція нормативно-правового регулювання галузі фінтех на прикладі діяльності установ-емітентів електронних грошей відповідно до змін, внесених до Директив СС про започаткування та здійснення діяльності установами-емітентами електронних грошей і пруденційний нагляд за ними, а також відповідна еволюція прав та обов'язків суб'єктів із надання фінансових послуг у країнах ЄС. Доведено доцільність застосування системного підходу до нормативно-правового регулювання галузі фінтех як такого, що враховує об'єктивні процеси самоорганізації та саморегулювання сучасних систем, розвиток різноманіття системоутворюючих зв'язків та інтенсивну інтеграцію правових норм і правовідносин як прояву інтегративної юриспруденції з метою забезпечення формування та розвитку якісної екосистеми фінтеху в рамках соціологічної юриспруденції з урахуванням соціальних, економічних та інформаційних аспектів розвитку суспільних відносин у динаміці.

Ключові слова: фінтех, нормативно-правове регулювання, підходи до нормативно-правового регулювання, електронні гроші, електронні платежі. 


\section{Summary}

Bukharin H.O. Research of approaches of legal regulation of the fintech industry on the example of regulation of the business of electronic money institutions. Article.

In the context of global financial globalization, rapid information and technological development along with the absence of an effective system of regulators for coordinating the activities of the world economic and financial institutions on the issues of forecasting directions of economic development, risks of crisis manifestations, etc., new financial services institutions are formed and developed, which in turn actualizes the need to determine their legal status and create a balanced regulatory framework of their activities. The article discusses approaches to the legal regulation of the fintech industry on the example of the business of electronic money institutions, presents and analyzes the classifications of approaches and the criteria by which they are formed. Existing electronic payment models are presented: Asian, European and American - each with its own specific features, their advantages and disadvantages are identified. The evolution of the legal regulation of the fintech industry as an example of the business of electronic money institutions has been investigated, in line with the changes made to the EU Directives on the establishment and implementation of electronic money institutions and prudential supervision, as well as the corresponding evolution of rights and responsibilities of financial services entities in the EU. The expediency of applying a systematic approach to the legal regulation of the fintech industry as one that takes into account the objective processes of self-organization and self-regulation of modern systems, the development of a variety of system-forming relationships and the intensive integration of legal norms and relationships as a manifestation of integrative jurisprudence, and with the aim to develop qualitative ecosystem of fintech within the framework of sociological jurisprudence taking into account social, economic and informational aspects of social relationship development in dynamics has been proven.

Key words: fintech, legal regulation, approaches to legal regulation, electronic money, electronic payments. 